\title{
Destinasi: Kolaborasi Kreatif Musik Digital, Puisi dan Tari
}

\author{
Junita Batubara ${ }^{1}$ \\ Program Studi S-1 Seni Musik, Fakultas Bahasa dan Seni, Universitas HKBP Nommensen, Medan
}

\begin{abstract}
Destination: Creative Collaboration of Digital Music, Poetry, and Dance. This research discusses implementing a music score into a collaboration of digital music, dance and poetry. The integration of the three arts is done by symbolizing human life from birth to adulthood. As the creator of this "destination" composition, the researcher intends to add to her repertoire by combining three different arts, namely, digital music, dance, and poetry. This compositional work was created by using qualitative, practice-based, practice-led and ethnographic methods. The process of making this work was by analyzing the data of music score taken from the results of field exploration, and in combination with poetry and the data of dance script, which then processed into the laboratory desk. The result then was creating collaborative digital music, dance and poetry, based on the culture of human life and the author's background and life experiences. The work reflects the symbols of human life, which are revealed in the poem entitled Directions of Life. Initially, Destination's composition work was a composite work created using cross-cultural (combination) elements of Western and Malay music (gendang Malay). Furthermore, the work was processed into a collaboration that was carried out using motion, emotion, voice intonation and digital music. The result of the collaboration of Destination's compositions is to produce a performance that combines three different arts where music is the main focus in bringing out ideas and concepts of body movement and voice intonation from dancers and poetry readers. The ability to relate ideas or ideas to a musical concept and produce new work with three different arts can be used by musicians, practitioners, and educators in Indonesia.
\end{abstract}

Keywords: idea; concept; digital music; poetry; dance; composition work

\begin{abstract}
ABSTRAK
Penelitian ini mendiskusikan implementasi sebuah skor musik menjadi kolaborasi musik digital, seni tari dan puisi. Penggabungan ketiga seni tersebut dilakukan dengan cara symbol kehidupan manusia dari mulai lahir hingga dewasa. Peneliti sebagai pencipta karya komposisi destination ini bermaksud untuk menambah repertoar dengan menggunakan penggabungan tiga seni yang berbeda yaitu, musik digital, tari dan puisi. Karya komposisi ini diciptakan dengan menggunakan metode kualitatif, practice-based, practice-led dan ethnographic. Proses pembuatan karya tersebut dengan melakukan analisa data skor musik yang diambil dari hasil eksplorasi lapangan dan kombinasi dengan data script puisi dan tari kemudian diolah ke dalam desk laboratory. Hasilnya adalah terciptanya kolaborasi karya seni musik digital, tari dan puisi, berdasarkan budaya kehidupan manusia dan latar belakang penulis dan pengalaman kehidupan penulis. Di dalam karya tersebut mencerminkan symbolsymbol kehidupan manusia yang terungkap dalam puisi yang berjudul Arah Kehidupan. Awalnya karya komposisi Destination merupakan karya penggabungan yang diciptakan menggunakan silang budaya (kombinasi) elemen-elemen musik Barat, dan musik melayu (gendang melayu). Selanjutnya karya tersebut diolah menjadi sebuah kolaborasi yang dilakukan dengan perpaduan gerak, emosi, intonasi suara dan musik digital. Hasil dari kolaborasi karya komposisi Destination adalah menghasilkan sebuah pertunjukan perpaduan tiga ilmu seni yang berbeda dimana musik sebagai fokus utama dalam memunculkan ide-ide dan konsep gerakan tubuh dan intonasi suara dari penari dan pembaca puisi. Kemampuan untuk mengaitkan idea atau gagasan terhadap sebuah konsep musik, menghasilkan sebuah karya baru dengan kolaborasi tiga seni yang berbeda dimana bisa digunakan oleh musisi, praktisi, dan edukator di Indonesia.
\end{abstract}

Kata kunci: ide; konsep; musik digital; puisi, tari; karya komposisi

1 Alamat korespondensi: Program Studi S-1 Seni Musik, FBS, Universitas HKBP Nommensen, Medan. Jalan Sutomo No. 4A, Perintis, Kec. Medan Tim., Kota Medan, Sumatera Utara, 20235. E-mail: junitabatubara@ uhn.ac.id; HP: 0811648026. 


\section{Pendahuluan}

Dewasa ini, seni bisa dilihat dalam intisari ekspresi dari kreativitas manusia. Seni sangat sulit untuk dijelaskan dan juga sulit dinilai, bahwa masing-masing individu memilih sendiri peraturan dan parameter yang menuntunnya atau kerjanya, masih bisa dikatakan bahwa seni adalah proses dan produk dari memilih medium, dan suatu set peraturan untuk penggunaan medium itu, dan suatu set nilai-nilai yang menentukan apa yang pantas dikirimkan dengan ekspresi lewat medium itu, untuk menyampaikan baik kepercayaan, gagasan, sensasi, atau perasaan dengan cara seefektif mungkin untuk medium itu. Sekalipun demikian, banyak seniman mendapat pengaruh dari orang lain masa lalu, dan juga beberapa garis pedoman sudah muncul untuk mengungkap gagasan tertentu lewat simbolisme dan bentuk. Sebagai cikal bakal dalam sebuah kreativitas, sangat membantu untuk memahami bahwa komposer umumnya tidak menciptakan sesuatu dari ketiadaan ketika mereka menulis karya baru. Sebaliknya, mereka menciptakan dari pengalaman baik masa lalu atau pengalaman saat ini-pemahaman mereka tentang teori musik, apa yang mereka pelajari dan dengarkan, apa yang ingin mereka dengar sendiri-atau mungkin bahkan hanya menjawab beberapa pertanyaan musik tertentu yang mereka miliki. Terciptanya sebuah karya seni, baik itu karya seni baru tidak terlepas dari bagaimana kreativitas komposer dalam melakukan garapan. Wujud sebuah karya seni pada dasarnya adalah representasi pengalaman pengalaman estetis seorang seniman ketika mencoba mencari jawaban atas apa yang ada di balik gejala yang ditangkap oleh inderanya. Musik merupakan bagian yang terintegrasi dari berbagai macam elemen transmisi, salah satunya lewat eksistensi musik tersebut di masyarakat (Irawati, 2019). Oleh karena itu dalam melihat sebuah karya seni masalah bentuk dan isi karya adalah masalah yang saling berkait. Bentuk adalah segala hal yang membicarakan faktor intrinsik karya, mulai unsur, struktur, simbol, metafora dan lain sebagainya; sedangkan persoalan isi mempertanyakan nilai kognitif-informatif, nilai emosi-intuisi, nilai gagasan, dan nilai-nilai hidup manusia.
Ada dua pendapat tentang keberadan nilai dalam sebuah karya seni. Ada yang bependapat bahwa nilai seni sebuah karya terletak pada benda dan senimannya. Namun dapat pula pencarian hakekat seni dilakukan dari aspek penerima seni. Artinya nilai sebuah karya seni tidak terletak pada bendanya atau penciptanya, tetapi kepada penerimanya.

Pertama, sebenarnya tidak ada karya seni yang rumit dan buntu. Karya seni yang sejati, sebagaimana lembaga kebenaran yang lain, selalu jujur, jelas, dan transparan, sebab yang ingin dicapai adalah kebenaran. Struktur jiwa manusia, dalam hal perasaan, intuisi, bawah sadar dan berpikir, sama saja dari dulu hingga sekarang. Apa yang dirasakan dan dipikirkan manusia dimanapun sama. Hanya cara mengungkapkannya itulah yang berbeda beda; Terutama dalam aspek intrinsik struktur seninya. Penguasaan struktur inilah yang menjadi bagian vital yang harus dikuasai oleh seorang seniman dalam berkarya. Tanpa penguasaan struktur sulit bagi seniman untuk mengolah dan mengungkapkan perasaan, pikiran serta pengalamannya menjadi sebuah informasi yang akan ditransmisikan pada publik seni (komunikan). Demikian juga publik seni, tanpa mengerti, memahami, menghayati struktur keindahan akan sulit menangkap maksud seniman lewat media yang dimiliki dan diolah.

Kedua, seperti telah disinggung sebelumnya bahwa kemunculan karya seni tidaklah bebas dari konteks nilai, baik nilai sosial, ideologi, politik maupun struktur sosial dan sebagainya atau sering disebut nilai ekstrinsik. Pemahaman terhadap konteks nilai inilah untuk Indonesia menjadi salah satu sumber masalah kesenjangan informasi yang terjadinya adanya dalam berkomunikasi. Di satu pihak seniman yang berlatar belakang pendidikan seni secara formal, di mana pengetahuan dan nilai nilai yang dipelajari mengacu pada nilai-nilai yang non Indonesia, sementara di fihak lain nilainilai modern yang ada dalam masyarakat belum menampakkan wujud bentuknya yang jelas dan nilai-nilai lama sudah tidak jelas pula.

Musik yang diciptakan digarap untuk memberikan kenyamanan bagi pendengar dan penikmat musik. Menurut Jamalus (1988: 1) musik itu adalah suatu hasil karya bunyi 
dalam bentuk lagu atau komposisi musik, yang mengungkapkan pikiran dan perasaan penciptanya melalui unsur-unsur musik, yaitu irama, melodi, harmoni, bentuk/ stuktur lagu, dan ekspresi sebagai satu kesatuan. Masyarakat modern sangat sadar bahwa musik merupakan sebuah peristiwa yang mengalir. Dengan melewati batas ruang dan waktu, musik dapat mendefinisikan dirinya sendiri tanpa bantuan seni lainnya. Beberapa konsep baru lahir, dikembangkan, atau bahkan diciptakan, tetapi terkadang apa yang telah dilakukan oleh para pelakunya menimbulkan pertanyaan tentang identitas kultural masyarakat. Dalam proses penciptaan karya baru memiliki baberapa teknik dalam penggarapannya. Teknik ini yang nantinya akan menambah keindahan hasil penciptaan karya dan menjadikan sebuah karya komposisi baru.

Komposisi Destination sepenuhnya terinspirasi dari pengalaman hidup disekitar Tanjung Malim Malaysia dan juga pengalaman dari penari (koreografer) ketika mengalami pergumulan hidupnya. Pertama yang paling berbeda adalah cara berkomunikasi walaupun satu rumpun yaitu Melanesia tetapi kata yang sama bisa berbeda makna sehingga sering sekali terjadi miskomunikasi. Destination maksudnya disini adalah arah tujuan hidup yaitu menyelesaikan studi. Komposer menciptakan karyanya sehubungan dengan pengalaman hidup bekerja sebagai dosen internasional di mana budaya kehidupan dan suasana akademik yang berbeda dengan negaranya. Hal ini juga didukung oleh pendapat dari Saraswati (2013: 160) mengatakan bahwa lingkungan menjadi faktor inspirasi dalam seperangkat konsep institusi dalam masyarakat yang terlibat dan membentuk jaringan kegiatan sosial dan budaya seperti kondisi ekonomi, sosial, pendidikan di lingkungan di mana mereka tinggal, dengan siapa saja mereka sering berinteraksi, di mana mereka bekerja dan lain sebagainya. Menurut Batubara (2020: 116) bahwa Komposisi musik dengan penerapan elemen lintas budaya yang menggabungkan musik Barat dan musik penduduk tempatan dapat menjadi seabuah ide di mana ide menjadi konsep yang menghasilkan suatu karya dan dapat dilakukan penelitian baru dengan berbagai pendekatan-pendekatan secara musik komposisi.
Konsep dalam hal ini terkait juga dengan konsep kebudayaan. Menurut Nursulistiyo (Aji \& Suyoto, 2019: 82), bahwa konsep kebudayaan bisa didefenisikan sebagai keseluruhan cara bertingkah laku manusia dalam kehidupannya yang menjadi suatu identitas. Hal inilah yang semakin memperkuat komposer untuk menciptakan karya komposisi yang berjudul Destinasi. Adapun pendekatan komposisi yang dilakukan komposer adalah silang budaya yaitu budaya melayu dan budaya musik Barat. Pengaruh dari silang budaya tersebut masuk dalam komposisi musik secara damai Penetration Pasifique, tidak menimbulkan konflik atau paksaan, seperti Penetration Violante. Justru dengan sifat keterbukaan ini dengan silang budaya Melayu dan budaya Barat, telah terjadi pertemuan budaya menjadi sebuah akulturasi, di mana telah terjadi proses sosial yang timbul bila suatu kelompok manusia dengan suatu kebudayaan tertentu dihadapkan dengan unsur-unsur dari suatu kebudayaan asing yang berbeda sedemikian rupa, sehingga unsur unsur asing tersebut lambat laun diterima dan diolah ke dalam kebudayaan sendiri (Koentjaraningrat, 1974: 152). Akulturasi merupakan proses pengambilan dan pemberian unsur kebudayaan tertentu dari dua jenis budaya, akibat adanya pertemuan kelompok-kelompok yang berlatar belakang budaya berbeda di tempat atau lokalitas yang sama. Akulturasi silang budaya ini memberikan pengaruh tidak hanya sekedar revolusi, di mana satu harus musnah untuk diganti dengan yang baru. Kehidupan budaya yang akan selalu mengalami proses akulturasi, memang tidak bisa ditawar-tawar lagi selama manusia masih menghendaki munculnya sebuah karya. Akulturasi merupakan proses di mana satu kelompok manusia dari satu kebudayaan tertentu mengalami pegeseran nilai. Pengaruh kebudayaan asing lambat laun diterima dan diolah ke dalam kebudayaan sendiri tanpa menyebabkan hilangnya kepribadian itu sendiri. Dalam proses perubahan budaya atau 'cultural dynamic', biasanya disertai dengan kritik, konflik, dan pembatalan nilai-nilai lama, kemudian menyeleweng dari hasil yang telah dicapai, ataupun membawa serta penghalusan warisan kebudayaan dan peningkatan nilai-nilai yang terkandung di dalamnya. 
Komposer juga mengatakan bahwa beliau melakukan ini layaknya seperti 'parawisata komposisi'. Berdasarkan pengalaman inilah maka komposer menuangkannya ke dalam sebuah konsep yaitu dengan bentuk skor musik dan diubah dalam program musik digital. Selanjutnya komposer melakukan suatu kreativitas yaitu dengan melakukan suatu kolaborasi antara tari dan puisi. Kemampuan penari untuk menciptakan dan merealisasikan ide yang tumbuh dalam benaknya untuk diwujudkan di ruang publik. Karya tari adalah hasil dari sebuah proses penciptaan, melalui kreativitas tersebut seniman dapat melakukan transformasi pengalaman batinnya ke dalam sebuah karya seni yang akan dikomunikasikan kepada orang banyak (Rustiyanti, 2017: 223).

Menurut Schwartz dan Godfrey (1993: 129-135), bahwa sistem kerja dalam pembuatan suatu karya musik dengan menggunakan musik elektronik, digital dan instrumen aslinya dalam sebuah studio rekaman, menawarkan situasi kerja yang ideal bagi seorang komposer. Setiap detail potongan-potongan karya komposisi dapat diasah, diuji dan disempurnakan sampai komposer puas dengan produk akhir. Apalagi setelah karya komposisi tersebut direkam, maka komposer menjamin sempuran disetiap karya komposisi yang sudah dikompail. Komposer melakukan uji coba untuk menggabungkan instrumen musik digital, elektronik dan instrumen musik asli (contohnya, violin, flute dan vokal). Penggabungan ini dilakukan dengan cara memasukan suara-suara dari setiap alat musik yang asli, kemudian ditambah dengan musik digital (synthesizer) dan musik elektronik (gitar elektrik).

Menurut Soekanto (2009: 259) perubahan sosial memiliki rumusan, yaitu segala perubahanperubahan pada lembaga-lembaga kemasyarakatan di dalam suatu masyarakat, yang mempengaruhi sistem sosialnya, termasuk di dalamnya nila-inilai, sikap, dan pola perilaku di antara kelompokkelompok dalam masyarakat. Menurut Menurut Schwartz dan Godfrey (1993: 137) mengatakan bahwa ada 5 cara untuk melakukan ekstramusikal dalam sebuah pertunjukan yang ada unsur-unsur seni lainnya yaitu: (1) Rangsangan visual, seperti pencahayaan, film, slide atau video, seperti diistilahkan dengan ekranisasi; (2) Gerak atau ucapan penari, aktor/aktris atau pelaku musik itu sendiri, dapat membuat suara musik yang dibangun oleh dirinya sendiri, misalnya tepuk tangan, siulan, hentakkan kaki, jentikan jari, tepuk dada, tepuk paha, dan sebagainya, seperti halnya musik internal yang dibangun oleh pemain itu sendiri (Rustiyanti, 2014: 154); (3) Benda fisik atau alat peraga, mulai dari barang sehari-hari hingga patung, lukisan dan bentuk seni visual lainnya; (4) Penggunaan ruang fisik secara kreatif, seperti penempatan atau pergerakan sumber suara yang tidak biasa-penyanyi atau pengeras suara diseluruh area pertunjukan; (5) Partisipasi penonton dalam pertunjukan dan/ atau komposisi suatu karya.

Berdasarkan trikotomi seni, yang memaparkan bahwa hubungan antara seni dan penelitian terdiri atas tiga hal yang secara krusial yaitu: penelitian dalam seni (research on the art), penelitian untuk seni (research for art), dan penelitian melalui seni (research in art). Seni pertunjukan telah menjadi sebuah disiplin ilmu yang mencoba menerapkan berbagai kajian dan metodologi yang integratif. Penelitian ini merupakan ekranisasi sebuah transformasi estetik seni pertunjukan sebagai sebuah disiplin ilmu mencoba dikembangkan dengan berbagai metode dan teorinya yang dikaitkan dengan industri digital (Rustiyanti, 2021: 189). Pendapat tersebut dan juga hasil dari pemikiran komposer yaitu dalam karyanya melakukan suatu kolaborasi dengan tiga seni yang berbeda yaitu musik yang merupakan hasil perekaman studio, seni tari dan puisi di mana ketiga hal tersebut didasari dari konsep segitiga sama sisi dan segitiga siku-siku. Adanya ide sebagai dasar dalam karya komposisinya tersebut di mana komposer menginterpretasikan kehidupan manusia yang mengalami berbagai masalah yang pada akhirnya bisa bangkit dari segala persoalan yang menimpa kehidupannya. Komposer tidak memberikan petunjuk kepada audiens dengan tujuan agar karyanya dapat dimaknai sesuai dengan interpretasi oleh penonton yang melihat pertunjukan karyanya. Gambar ide yang didasari daripada segitiga sama sisi dan siku-siku dapat dilihat pada Gambar 1.

Candy (2006) menyatakan, "Jika penelitian mengarah terutama pada pemahaman baru tentang 
praktik, itu adalah praktik yang dipimpin”. Proses penyusunan biasanya mengarah pada keputusan yang dibuat dalam proses kreatif seperti yang diterapkan ke dunia nyata. Komposisi secara umum adalah proses hibrida, karena hasil utamanya adalah produk yang unik. Metodologi individual setiap komposer bervariasi. Menurut Suyoto (2020: 63) mengatakan bahwa penafsiran dalam berkarya bias menggunakan metode interpretasi dan analisis garap. Pemaparan dan penarikan kesimpulan dilakukan dengan metode induktif. Penelitian ini dilakukan dengan menggunakan metode yang sebagian besar bersifat kualitatif (berbasis praktik, praktek-dipimpin, dan otomatis) dalam komposisi dan persiapan untuk kinerja secara informal dalam pemilihan musik tradisional yang ada di Tanjung Malim Malaysia untuk sebuah inspirasi.

\section{Metode Penelitian}

Dalam komposisi musik, metodologi umumnya disebut sebagai 'proses kreatif'. Membicarakan komposisi musik, memang tidak lepas dari proses kreatif, yaitu mengemukakan sesuatu hal yang selalu baru, segar, dan terus mengalir. Oleh karena itu, karya Destinasi sebagai kolaborasi musik dengan tari dan puisi, tentu saja komposisi musik ini tidak lepas dari hal-hal seperti gerak tubuh tanpa partitur, tanpa teks, tanpa instrumen, tanpa tradisi, tanpa reportoar, tanpa titik puncak pencapaian, dan aturan yang

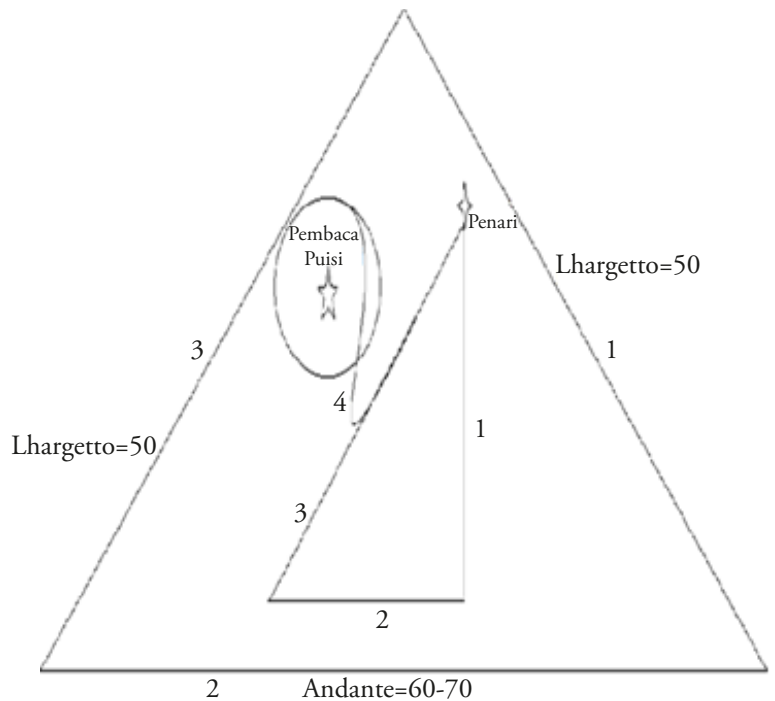

Gambar 1: Ide dan konsep Karya Komposisi Destinasi. (Illustrator: Junita Batubara, 2021) ketat, tanpa acuan yang riil, tanpa retorika sebagai bentuk karya baru yang original. Dalam komposisi Destinasi, setiap proses kreatif gerakan itu sedikit berbeda. Secara umum, situasi keadaan lingkungan bermasyarakat di Tanjung Malim Malaysia dengan tujuan tertentu. Kemudian karakteristik lingkungan Tanjung Malim 'diterjemahkan' ke dalam musik menggunakan pengalaman dari komposer dalam menciptakan karya komposisinya dengan suarasuara alam sekitarnya, musik tradisional yaitu gendang melayu, rebana perak dan gong, suara air sungai, flute, trombone, viola, double bass, piano, synthesizer, bells) dan musik tradisional (Rebana Perak), vokal dan soundscape yang terkait dengan budaya melayu sekitaran Tanjung Malim. Melalui kombinasi pengalaman pribadi dari komposer dan penelitian mengenai siklus kehidupan seseorang di Tanjung Malim dan sekitarnya dibangun dengan menggambarkan kehidupan pribadi seseorang yang mengalami berbagai rintangan hidup dalam budaya melayu dari Malaysia.

\section{Hasil dan Pembahasan}

Keberadaan musik adalah sebagai kreativitas dari salah satu fakta musikal sebuah seni pertunjukan yang masih hidup, dan takkan mungkin hilang begitu saja. Hal ini disebabkan kokohnya akar seni tradisi yang dipelihara oleh masyarakat pendukungnya. R.M. Soedarsono mengatakan, munculnya arus perkembangan seni sebagai Multikulturalisme atau Pluralisme yang menghargai keberadaan karya seni dalam bentuk dan gaya apapun (2002: 112). Sehubungan dengan pendapat R. M. Soedarsono, guna membahas konsep penulisan dalam struktur musik, penulis sengaja mengambil sebagian konsep musik Barat, sebagai salah satu pendapat untuk mengacu dasar pemikiran yang demikian, penulis berpedoman kepada penyampaian Victor Ganap sebagai berikut. Kemudian strukturalisme musik dapat dimaknai dengan mempedomani pendapat Molino yang ditulis oleh Victor Ganap. Molino mengambil istilah poietic (proses penciptaan suatu karya seni) dari Gilson (1963), yang menekankan bahwa setiap karya musik pada dasarnya dilengkapi dengan eksistensi empirik, dengan realitas, 
sebagai suatu produk dari sebuah tindakan membuat sesuatu, kelahiran dari sebuah karya (Ganap, 2003: 75).

Hasil pengamatan peneliti, komposer melakukan berbagai percobaan-percobaan untuk menghasilkan karya yang terbaik yaitu pertamatama menggubah komposisi musik menggunakan elemen-elemen musik Barat seperti: notasimelodi (pitch, durasi, dan tone), irama-ritme (penentu ketukan/beat), meter-birama (poly meter), tangga nada (kromatis), harmoni (paduan bunyi yang selaras), tempo (Lhargetto-AndanteLhargetto), dinamika (nuansa sedih-riang-dataragresif-datar), timbre (memiliki warna suara yang 'baru' dengan adanya percampuran musik tradisi/ rebana perak dan gong, suara air sungai, flute, trombone, viola, double bass, piano, synthesizer, bells) dan musik tradisional (Rebana Perak) dan vokal. Setelah melakukan berbagai percobaan maka komposer melakukan proses penulisan ide dan konsep dalam bentuk skor musik. Imajinasi suarasuara dan bunyi-bunyian sekitaran Tanjung Malim menjadi pilihan utama dalam penyampaian bahasa musik ke dalam skor musik. Pada notasi 1 dapat jelas dilihat bahwa setiap melodi dari instrumen musik yang digunakan dapat menggambarkan aktivitas-aktivitas yang dilakukan oleh masyarakat tempatan dalam melakukan kegiatan yang dimulai pagi hari hingga sore hari. Kegiatan-kegiatan yang dilakukan oleh masyarakat yang dimana masyarakat di Tanjung Malim Malaysia, lebih kepada orang pendatang. Yang dimaksud dengan orang pendatang adalah orang-orang yang mempunyai tujuan kerja sebagai dosen, pegawai, dokter, dan mahasiswa dimana mereka merupakan warga dari Universiti Pendidikan Sultan Idris Malaysia. Dengan keberagaman budaya tersebut, maka konsep musik yang diciptakan menggambarkan keberagaman budaya masyarakat tempatan dan pendatang. Salah satu contoh menggambarkan suasana dari Tanjung Malim dapat dilihat melalui melodi, dari instrument flute dan struktur keseluruhan melodi dengan ritem dan tempo yang berbeda-beda. $\mathrm{Hal}$ ini dapat dilihat dalam skor di bawah ini:

"Konsep Barat mengatakan bahwa musik adalah sebuah seni yang memadukan berbagai bunyi menurut aturan tertentu (yang berbeda menurut waktu dan tempat) untuk menyusun sebuah unit yang mempunyai durasi dan terdiri atas elemen-elemen sonoris. Dalam hal ini, musik didefinisikan menurut persyaratan dari produksinya sebagai sebuah seni, dan menurut materialnya yaitu bunyi-bunyian (Ganap, 2003: 78).

Kemudian strukturalisme musik dapat dimaknai dengan mempedomani pendapat Molino yang ditulis oleh Victor Ganap. Molino mengambil istilah poietic (proses penciptaan suatu karya seni) dari Gilson (1963), yang menekankan bahwa setiap karya musik pada dasarnya dilengkapi dengah eksistensi empirik, dengan realitas, sebagai suatu produk dari sebuah tindakan membuat sesuatu, kelahiran dari sebuah karya (Ganap, 2003: 75).

Hasil pengamatan peneliti, komposer melakukan berbagai percobaan-percobaan untuk menghasilkan karya yang terbaik yaitu pertamatama menggubah komposisi musik menggunakan elemen-elemen musik Barat seperti: notasimelodi (pitch, durasi, dan tone), irama-ritme (penentu ketukan/beat), meter-birama (poly meter), tangga nada (kromatis), harmoni (paduan bunyi yang selaras), tempo (Lhargetto-AndanteLhargetto), dinamika (nuansa sedih-riang-dataragresif-datar), timbre (memiliki warna suara yang 'baru' dengan adanya percampuran musik tradisi/ rebana perak dan gong, suara air sungai, flute, trombone, viola, double bass, piano, synthesizer, bells) dan musik tradisional (Rebana Perak) dan vokal. Setelah melakukan berbagai percobaan maka komposer melakukan proses penulisan ide dan konsep dalam bentuk skor musik. Imajinasi suarasuara dan bunyi-bunyian sekitaran Tanjung Malim menjadi pilihan utama dalam penyampaian bahasa musik ke dalam skor musik. Pada notasi 1 dapat jelas dilihat bahwa setiap melodi dari instrumen musik yang digunakan dapat menggambarkan aktivitas-aktivitas yang dilakukan oleh masyarakat tempatan dalam melakukan kegiatan yang dimulai pagi hari hingga sore hari. Kegiatan-kegiatan yang dilakukan oleh masyarakat yang dimana masyarakat di Tanjung Malim Malaysia, lebih kepada orang pendatang. Yang dimaksud dengan orang pendatang adalah orang-orang yang mempunyai tujuan kerja 
sebagai dosen, pegawai, dokter, dan mahasiswa dimana mereka merupakan warga dari Universiti Pendidikan Sultan Idris Malaysia. Dengan keberagaman budaya tersebut, maka konsep musik yang diciptakan menggambarkan keberagaman budaya masyarakat tempatan dan pendatang. Salah satu contoh menggambarkan suasana dari Tanjung Malim dapat dilihat melalui melodi, dari instrument flute dan struktur keseluruhan melodi dengan ritem dan tempo yang berbeda-beda. Hal ini dapat dilihat dalam skor pada Notasi 1 berikut:

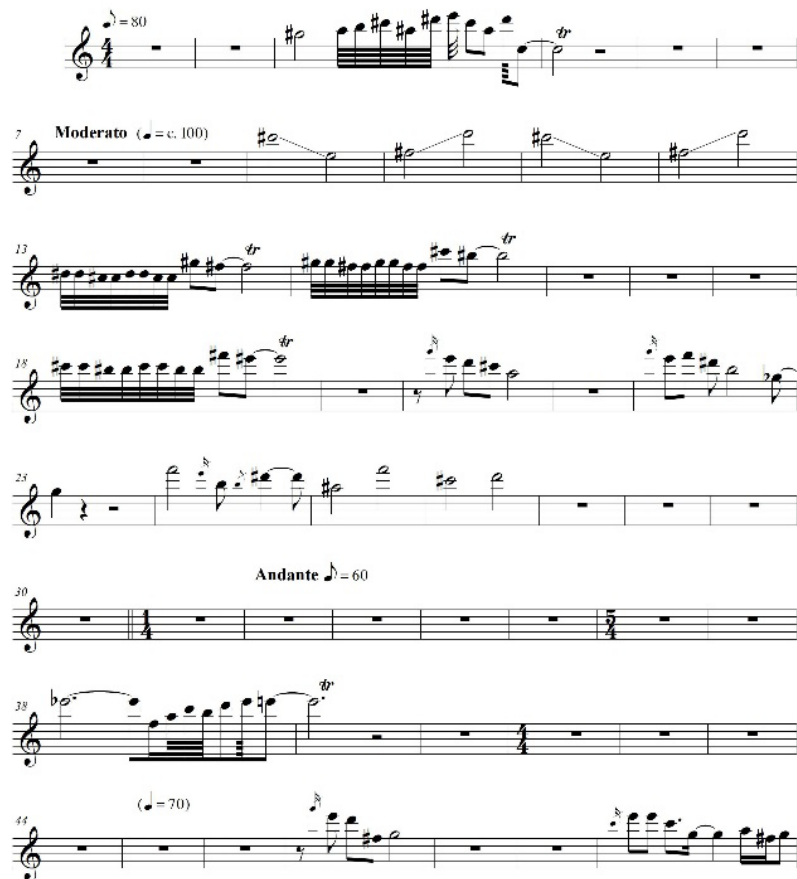

Notasi 1: Skor musik berjudul Activity untuk instrumen flute. (Illustrator: Junita Batubara, 2021)

Melihat gambar skor tersebut, maka dapat dilihat polymeter yang berbeda-beda yaitu.$)=80$; Moderato $(\cdot=$ c. 100); Andante $\boldsymbol{\emptyset}=60$ Dengan polymeter yang berbeda membuktikan dapat mempengaruhi sikap orang yang mendengarkan musik tersebut. Terkait dengan konsep musik yang diciptakan oleh komposer, maka muncullah ide bagaimana karya komposisi tersebut, bisa dipertunjukkan dengan tiga seni yang berbeda yaitu, musik, tari dan puisi.

Adanya hasil skor secara penuh, maka komposer melakukan penggabungan setiap instrumen musik dengan menggunakan, alat music secara aslinya dan musik digital dengan menggunakan program Cubase. Perekaman dilakukan di studio musik. Perekaman di studio dengan bantuan para pemain musik yang handal untuk direkamkan. Adapun pemain musik yang diperlukan untuk kebutuhan rekaman karyanya disesuaikan dengan alat-alat musik yang diperlukan seperti telah tertera di atas. Komposer memberikan karya bakunya dalam bentuk skor kepada para pemain sebelum melakukan perekaman. Salah satu bentuk skornya ada pada Notasi 2 berikut:
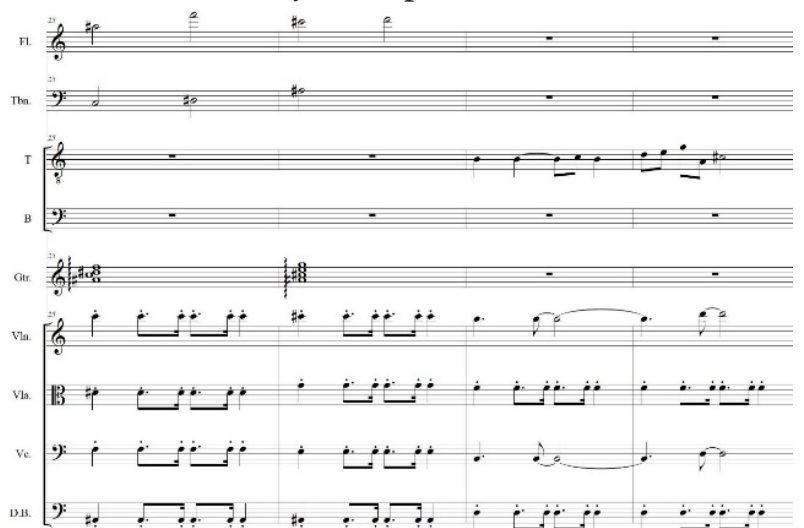

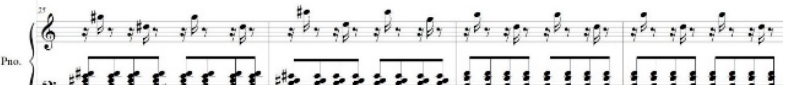

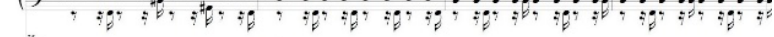
span

im.

Gong II

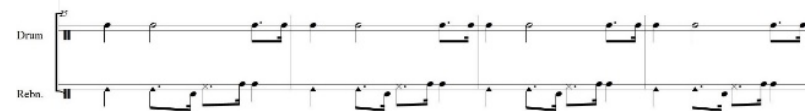

Notasi 2: Skor musik berjudul Activity. (Illustrator: Junita Batubara, 2021)

Setelah dilakukan perekaman terhadap seluruh alat musik yang diperlukan maka pada Gambar 2 adalah hasil dalam bentuk digitalnya.

Kemudian, komposer beserta temannya seorang pengajar sastra Inggris yaitu Rotua Pangaribuan juga menuliskan puisi sebagai gambaran kehidupan dimana puisi tersebut dengan judul Tujuan Arah Hidup. Menurut Komposer, puisi yang diciptakan berdasarkan pengalaman hidup seseorang yang tinggal di daerah Tanjung Malim Malaysia. Syair puisi yang diciptakan adalah sebagai berikut:

Seiring bumi berputar dan sang surya tiada hentinya menyinari semesta alam... pertemuan dalam pelepas rindu antara anak manusia...yang tak berhenti menelusuri lautan lepas dalam mencari makna... menyusuri suratan hidupnya...

Mengapa dalam kehidupan ada suka, duka, tawa, tangisan, gempa bumi, erupsi, tsunami yang menguji iman, kemudian ada 
berhenti atau berjalan terus?...

Kemana tujuan jejak langkah-langkah dalam mencari arah kehidupan?...

Dimanakah kelak kita harus tetap bertahan? Bertanya pada sang malam yang diam membisu, mengapa jiwa-jiwa semakin gersang?...

Mampukah kita meniti diri menghadap sang penguasa alam?

Tanpa harus meneteskan airmata...

Apayang mau dicari untuk sebuah kepastian tujuan hidup?...

Apakah hidup adalah kematian?

Atau...tujuan hidup adalah pengabdian dan kepasrahan pada Illahi?

Maknailah tujuan hidupmu dan

bertanggungjawablah....

Setelah puisi tersebut direalisasikan, maka komposer memasukkan setiap kalimat-kalimat puisinya ke dalam bentuk gaya bernyanyi sprechstimme (gaya bernyanyi seperti berpidato) dengan menentukan grafik wave di mana jika garis grafik wave ke bawah maka merupakan nada $G$ (sol) sebagai nada terendah dan nada $\mathrm{E}$ (mi) sampai dua oktaf menjadi nada tertinggi untuk membacakan puisi dengan gaya Sprechstimme. Tetapi begitupun komposer juga memberikan kebebasan kepada pembaca puisi yaitu Rotua Pangaribuan dalam mengeksplorasi setiap kalimat dalam mencapai nada-nada dan melodi yang diinginkan oleh komposer. Gambar 3 adalah skema bentuk puisi yang diciptakan komposer.

Setelah puisi tersebut direalisasikan, maka komposer memasukkan setiap kalimat-kalimat puisinya ke dalam bentuk gaya bernyanyi

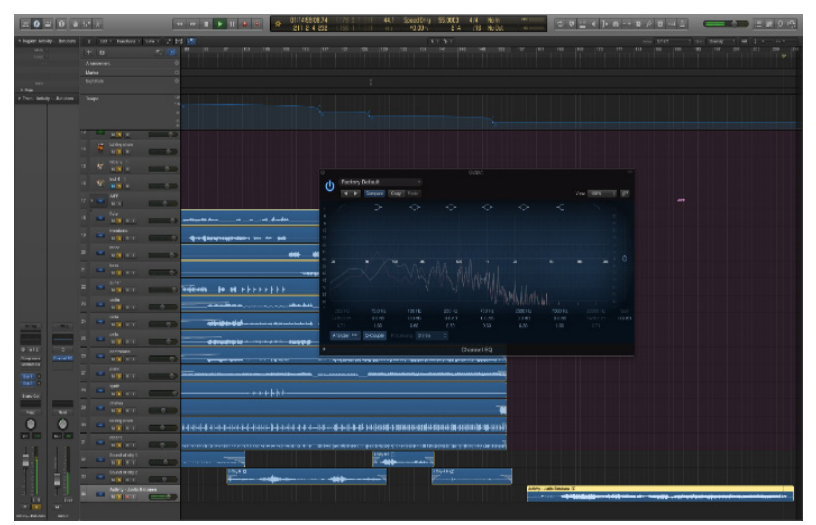

Gambar 2: Hasil perekaman dalam bentuk waveform. (Illustrator: Junita Batubara, 2021) sprechstimme (gaya bernyanyi seperti berpidato) dengan menentukan grafik wave di mana jika garis grafik wave ke bawah maka merupakan nada G (sol) sebagai nada terendah dan nada $E$ (mi) sampai dua oktaf menjadi nada tertinggi untuk membacakan puisi dengan gaya Sprechstimme. Tetapi begitupun komposer juga memberikan kebebasan kepada pembaca puisi yaitu Rotua Pangaribuan dalam mengeksplorasi setiap kalimat dalam mencapai nada-nada dan melodi yang diinginkan oleh komposer. Gambar 3 adalah skema bentuk puisi yang diciptakan komposer.

Musik dan puisi yang telah dibuat lengkap komposer, selanjutnya dilakukan kolaborasi dengan seorang penari yang bernama Jefri yaitu seorang penari handal yang selama ini banyak melakukan kolaborasi dengan seniman-seniman lainnya khususnya di kota Medan, Sumatera Utara. Seperti halnya, dalam metode TaTuPa (Tabuh Tubuh Padusi) musik merupakan elemen kedua untuk tari (yakni sebagai pengiring) dan satu elemen yang hampir tidak dapat dipisahkan karena dapat memberikan jalinan melodi, ritme, dan timbre dalam struktur komposisi musik untuk iringannya. Hal ini sangat menentukan struktur dramatik, serta aksen-aksen yang diciptakannya yang memberi nafas dan jiwa yang diperlukan untuk membantu menghidupkan suasana (Rustiyanti, 2019: 162). Komposer memberikan kebebasan kepada penari untuk melakukan gerakan-gerakan tariannya tetapi menyesuaikan dengan konsep yang sudah diberikan kepada sang penari. Untuk proses ini, penari membutuhkan waktu selama 2 bulan dalam mencari inspirasi dan eksplorasi gerakan-gerakan tarian yang disesuaikan dengan

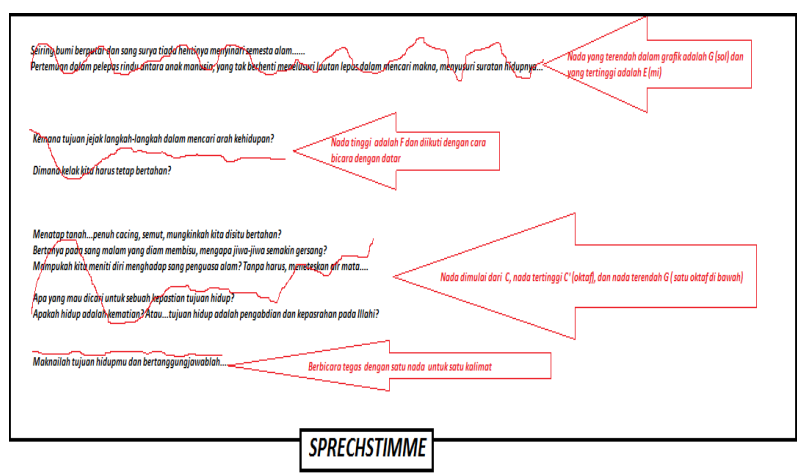

Gambar 3: Skema Puisi Tujuan Arah Kehidupan dalam format sprechstimme. (Illustrator: Junita Batubara, 2021) 
konsep musik dan puisi yang sudah diberikan oleh komposer. Kemudian penari (koreografer) mengeksplore motif-motif gerak berdasarkan gerakgerak melayang, stakato, colapse (kolep)/gerakan setengah jatuh, mengalir dengan menambahkan aksen (hentakan) gerak dan level (tinggi rendahnya gerak) yang menggambarkan kelahiran seorang insan. Penari dalam proses penciptaan sering terjadi pergulatan, pergumulan yang terus bergerak bolak balik antara motivasi dengan angan-angan akan wujud bentuk akhirnya. Konsentrasi terhadap fase-fase proses kreatif mungkin saja dapat berubah atau dengan kata lain tidak berurutan tetapi secara acak dapat dimulai dari fase apa saja tergantung menurut keperluan tari yang diinginkan oleh komposer musik. Proses kreatif ini dialami penari sebagai satu kesatuan yang utuh dari keseluruhan fase-fase proses kreatif, dan bukan suatu deretan peristiwa yang harus berurutan pelaksanaannya. Dengan demikian, proses kreatif tidak terikat oleh batasan-batasan apapun, tetapi justru yang paling penting adalah percikan-percikan ide yang sangat diperlukan, atau meminjam istilah teori fisika Quantum yang diadopsi oleh M. Dwi Marianto "potensi-potensi virtual apa saja yang bisa berkembang atau dikembangkan," terutama poin-poin berikut ini: (1) Realitas itu dinamis; (2) Memahami realitas tidak boleh bersikap linier atas realitas itu, dalam arti lebih mengutamakan melihat kemungkinan-kemungkinanan serta mengantisiasi daripada bergayut pada kepastian; (3) Realitas baru akan ada/terasa/nampak ketika kita mau dan mampu melihatnya; (4) Realitas inti dari setiap makhluk bukanlah atom yang bersifat tunggal, melainkan suatu dualitas partikel/gelombang,

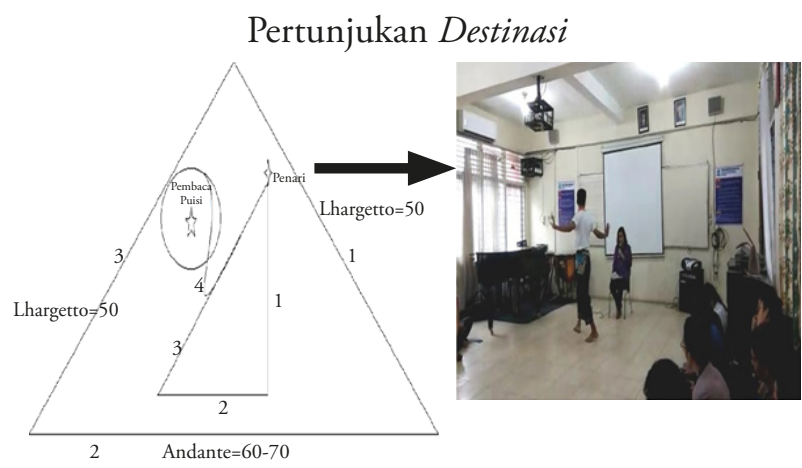

Gambar 4: Konsep karya Destinasi yang diaplikasikan dalam sebuah pertunjukan seni. (Illustrator: Junita Batubara, 2021) gelombang dan partikel saling melengkapi dan bertukar-tukaran tempat; (5) Realitas yang akan mengaktual sangat tergantung dari bagaimana pengukuran dilakukan, dalam hal ini sifat alat pengukur mempengaruhi hasil pengukuran (Marianto, 2004).

Setelah dilakukan latihan bersama beberapa kali antara pembaca puisi, penari dan musik yang sudah dalam bentuk rekaman mp3 dan komposernya, maka dilakukanlah pertunjukan dimana pertunjukan karya Destinasi ini terlaksana pada 28 September 2018 dengan durasi 7 menit bertempat di ruangan Beethoven FBS UHN pukul 14.00 WIB di acara kologium musik.

Berangkat dari sebuah ide kemudian dijadikan sebuah konsep dan hasilnya dilakukan dalam sebuah pertunjukan yang memiliki nilai tinggi di mana ada unsur-unsur penyampaian pesan kehidupan kepada audiens adalah merupakan salah satu alternatif dalam berkarya. Artinya dalam berkarya juga membutuhkan proses panjang hingga sampai ke sebuah pertunjukan dan begitu juga dengan kehidupan. Penyampaian ide dengan tahap proses kreatif terbagi dalam beberapa fase yaitu: (1) Sen-sing (merasakan), belajar mengamati yang ada di sekelilingnya atau peristiwa yang sering terjadi atau yang kita alami sendiri kemudian diserap dan dirasakan secara mendalam. Kemudian menyadari apa yang kita tangkap dari kesan penginderaan; (2) Feeling (menghayati), menghayati penginderaan yang kita tangkap dari peristiwa kehidupan atau temuan-temuan yang dianggap menarik menjadi milik kita akan sensasi sensasi dalam tubuh; (3) Imaging (mengkhayalkan), penginderaan yang kita tangkap menjadi respon khayalan dan menciptakan khayalan baru yang berkembang dan muncul berganti-ganti dengan cepat seperti kaleidoskop; (4) Transforming (mengejewantahkan), sehingga menemukan kualitas-kualitas estetis secara integral yang berkaitan dengan khayalannya (yang masih bersifat abstrak) yang kemudian dikonkritkan dengan mencurahkan segala pikir untuk diwujudkan menjadi ide-ide gerak yang diinginkan; (5) Forming (memberi bentuk), gerak terbentuk secara alamiah berdasarkan khayalan kemudian digabungkan dengan unsur-unsur estetik tarian. 
Fase-fase ini merupakan struktur kerangka proses kerja bagi pengalaman koreografi yang menggambarkan saluran dan keterkaitan dari berbagai fase dari proses tersebut (Hawkins, 2003).

\section{Kesimpulan}

Kolaborasi kratif musik digital dengan puisi dan tari, secara garis besar dapat dilihat bagaimana kreativitas komposer dalam menyusun dan bagaimana musik itu ditransformasikan: (1) Musik sebagai objek estetik memahami musik, dalam pandangan ini, mengharuskan kita untuk menangkap asumsi mendasar yang menentukan apa yang didengar dan dilihat di dunia fenomenal dan struktur formalnya untuk melihat bagaimana hal itu dibuat; (2) Musik sebagai simbol terkait dengan gagasan musik sebagai objek estetika adalah pandangan lain yang mencapai keunggulan di bagian akhir abad ke-20, dan menandakan bagaimana musik dirasakan dan memiliki makna bagi penciptanya dan publik. Para peneliti yang menggunakan pandangan ini dalam meneliti musik termasuk psikolog musik yang mempelajari bagaimana orang mendengar, mempersepsikan, memikirkan atau belajar mengembangkan kemampuan dan keterampilan khusus, dan membuat musik. Mengartikulasikan sifat simbol musik juga mengharuskan kita mengakui pentingnya imajinasi dan intuisi sebagai alat untuk memahami sistem simbol yang inheren dan ambigu; (3) Musik sebagai kegiatan praktis musisi harus memiliki pengetahuan prosedural untuk terus membuat musik, karena keterampilan teknis dan kritis yang didapat oleh para ahli digunakan terutama untuk membuat musik daripada membuat sebuah teori tentangnya. Sementara dalam mempraktikkannya, seorang pemusik selalu berpikir tentang musik secara abstrak dan teoretis. Fokus utama mereka adalah pada apa dan bagaimana sebuah lagu itu dinyanyikan dan sebuah instrumen harus dimainkan; (4) Musik sebagai pengalaman alih-alih berfokus pada perolehan keterampilan teknis dan kritis seperti yang terlihat pada pandangan musik sebagai praktik, citra ini memungkinkan orang untuk menghubungkan sifat pengalaman musik tertentu mereka melalui sarana, seperti jurnal, percakapan, dan artefak musikal (misalnya pertunjukan solo dan ensambel dalam setting tradisional, rekaman, situs web, dan pertunjukan yang dihasilkan secara elektronik); (5) Musik sebagai agensi citra musik sebagai agensi merujuk pada nilai musik sebagai sarana untuk mencapai politik, sosial, agama, psikologis, pendidikan, atau ekonomi, dan kebajikan moral menindas atau membebaskan orang, mengubah tradisi musik dan pendidikan dan masyarakat luas, dan meramalkan masyarakat masa depan. Dalam hal ini, nilai musikal muncul karena pentingnya tujuan lain daripada kelebihan intrinsiknya sebagai wujud musik untuk musik. Tidak seperti musik sebagai narasi, musik sebagai agensi ini merupakan sarana untuk mencapai tujuan lain. Sebagai kekuatan sosial, politik, agama, ekonomi, dan psikologis, musik mencerminkan nilai kelembagaan dan pribadi, serta membantu membentuk institusi tempat musik ini menjadi bagian, dan individu yang membentuk masyarakatnya.

Adanya konsep pertunjukan Destinasi dari komposer, penari (koreografer) mengeksplore motif-motif gerak berdasarkan gerak-gerak melayang, stakato, colapse (kolep)/gerakan setengah jatuh, mengalir dengan menambahkan aksen (hentakan) gerak dan level (tinggi rendahnya gerak) yang menggambarkan kelahiran seorang insan (Gerakan pertama dalam musik Lhargetto $=50$ ). Gerakan kedua dalam musik (Andante $=60-70$ ), koreografer menggunakan explore gerak melayang, stakato (patahan gerak) dan kolep (gerakan jatuh) untuk menggambarkan suka duka kehidupan. Dan gerakan ketiga dalam musik (Lhargetto $=50$ ), koreografer menggunakan gerak mengalir dimana menggambarkan semua kembali lagi kepada asalnya (Sang Pencipta)

Komposisi musik merupakan 'luahan' ide atau gagasan yang tercetus dalam sebuah konsep musik, dan menghasilkan sebuah karya dimana hal ini kreativitas komposer yang bisa dijadikan sebagai karya ilimiah yang teruji. "Destinasi" (Destination) adalah sebuah karya komposisi musik modern dengan kolaborasi puisi dan tari yang terinspirasi oleh interaksi komposer dengan kehidupan dilingkungan area Tanjung Malim Malaysia. 
Karya 'Destinasi' telah dipertunjukkan pada tanggal 28 September 2018 dengan durasi 7 menit bertempat di ruangan Beethoven FBS UHN. Musik diciptakan dalam bentuk ensambel (gabungan instrumen Barat, tradisi, suara air sungai dan vokal). Komunikasi antara komposer, pembaca puisi dan penari sangat membantu untuk berlangsungnya sebuah kolaborasi pertunjukan dimana pembaca puisi dan penari mengeksplorasi intonasi suara dan gerakan-gerakan dalam tarian sesuai dengan konsep komposer. Kegiatan ini dilakukan dalam Kologium yang sering dilakukan oleh Prodi Seni Musik FBS UHN. Untuk benar-benar mulai memahami teori dan aplikasi Kreativitas dalam Komposisi Musik, Prodi Seni Musik FBS UHN memiliki program minat utama salah satunya adalah teori dan komposisi yang menggabungkan teori dan praktek sehingga menghasilkan kompetensi lulusan yang mumpuni.

\section{Kepustakaan}

Aji, A. S., \& Suyoto. (2019). Konsep Mandheg dalam Karawitan Gaya Surakarta. Resital: Jurnal Seni Pertunjukan, 20(2), 81-95. https://doi.org/10.24821/resital.v20i2.3219

Batubara, J. (2020). The Rhythm of Birds: A Programmatic Musical Composition about Living in Tanjung Malim. Проблемы Музыкальной Науки / Music Scholarship, 2021(2), 116-125. https://doi. org/10.33779/2587-6341.2020.2.116-125

Candy, L. (2006). Practice Based Research: A Guide. Retrieved from https://www. creativityandcognition.com/resources/PBR Guide-1.1-2006.pdf

Ganap, V. (2003). Kompleksitas Fakta Musikal, Kembang Setaman Persembahan untuk Sang Mahaguru (A. M. H. Kusmayati, ed.). Yogyakarta: BP ISI Yogyakarta.

Hawkins, A. M. (2003). Bergerak Menurut Kata Hati: Metoda Baru dalam Menciptakan Tari (I. W. Dibia, ed.). Jakarta: Ford Foundation \& MSPI.

Irawati, E. (2019). A Transmission of Kêlèntangan Music among the Dayak Bênuaq of East Kalimantan in Indonesia. Malaysian Journal of
Music, 8, 108-121. https://doi.org/10.37134/ mjm.vol8.7.2019

Jamalus. (1988). Buku Pengajaran Musik Melalui Pengalaman Musik: Panduan Pengajar. Jakarta: Proyek Pengembangan Lembaga Pendidikan Tenaga Kependidikan.

Koentjaraningrat. (1974). Kebudayaan Mentaliet dan Pembangunan. Jakarta: Gramedia.

Marianto, M. D. (2004). Teori Quantum: Untuk Mengkaji Fenomena Seni. Yogyakarta: Lembaga Penelitian ISI Yogyakarta.

Rustiyanti, S. (2014). Musik Internal dan Eksternal dalam Kesenian Randai. Resital: Jurnal Seni Pertunjukan, 15(2), 152-162. https://doi. org/10.24821/resital.v15i2.849

Rustiyanti, S. (2017). Visualisasi Tando Tabalah Penari Tunggal dalam Photomotion Pertunjukan Rampak Kelompok Tari Minang. Mudra: Jurnal Seni Budaya, 32(2), 220-228. https://doi.org/10.31091/mudra.v32i2.112

Rustiyanti, S. (2019). Metode 'TaTuPa' Tabuh Tubuh Padusi sebagai Musik Internal Visualisasi Koreografi NeoRandai. Resital: Jurnal Seni Pertunjukan, 20(3), 161-175. https://doi.org/10.24821/resital.v20i3.3394

Rustiyanti, S. (2021). Ekranisasi AR PASUA PA: dari Seni Pertunjukan ke Seni Digital sebagai Upaya Pemajuan Kebudayaan. Mudra: Jurnal Seni Budaya, 36(2), 186-196. https://doi. org/10.31091/mudra.v36i2.1064

Saraswati, B. A. (2013). Perjalanan Hidup dan Kreatifitas Sang Pesindhen. Dewa Ruci: Jurnal Pengkajian Dan Penciptaan Seni, 8(2), 153-177. https://doi.org/10.33153/dewaruci. v8i2.1099

Schwartz, E., \& Godfrey, D. (1993). Music Since 1945: Issues, Materials, and Literature. New York City: Schirmer.

Soedarsono, R. M. (2002). Seni Pertunjukan Indonesia di Era Globalisasi. Yogyakarta: Gadjah Mada University Press.

Soekanto, S. (2009). Sosiologi: Suatu Pengantar. Jakarta: Rajawali Press.

Suyoto. (2020). Garap Rujak-rujakan dalam Sindhenan Gaya Surakarta. Resital: Jurnal Seni Pertunjukan, 21(2), 63-72. https://doi. org/10.24821/resital.v21i2.4365 